\title{
Editor's Introduction: Belgium, Diversity and Sociological Sub-Worlds
}

\section{T. Nichols ${ }^{1}$}

Published online: 5 June 2020

(C) Springer Science+Business Media, LLC, part of Springer Nature 2020

This issue features a set of papers about sociology in Belgium, including an examination of the discipline's history there, as well as selected issues in current thought and practice. Special thanks are due to Professors Kaat Louckx and Raf Vanderstraeten, who solicited the papers, read and commented on early drafts, communicated with contributors, suggested reviewers and assisted in other ways in producing these articles.

In their guest editors' introduction and in their article on sociology in "great little Belgium," Louckx and Vanderstraeten point to important divisions and barriers in society that are reproduced in academia. The most basic of these result from the organization of Belgium in contrasting ethnic, cultural and linguistic domains. The larger group, the Dutch-speaking community of Flanders, inclines more toward German and Anglo traditions and intellectual circles, while the minority French-speaking community of Wallonia and Brussels inclines more toward the French counterparts of these. The split is comparable to that between French and Anglo sociology in Canada, which was discussed in this journal in 2002. Louckx and Vanderstraeten also point out another important consequence of the partition, which is the trend toward a regional, rather than a national sociology.

Stefan Hellemans further develops the theme of division in a highly insightful article about self-contained worlds, which have acquired the name "pillars" in Belgium. The related term, "pillarization" ("verzuiling" in Dutch) is also widely used. Within Belgium, differentiated Catholic, Socialist and Liberal realms have been basic structural components of national life, including academia, for many decades. In neighboring Netherlands, these same domains, along with a Protestant pillar, have likewise shaped social relations. The thesis of Hellemans's article is that such self-contained worlds are hardly unique to these national settings, and that there is a need for a far more extensive, international literature on the topic.

Marc Poncelet contributes a highly detailed historical account of the relationship between the discipline of sociology and the politics of colonial expansion and colonial administration. The particular context is the acquisition of the Congo as a personal

L. T. Nichols

ltnichols@retiree.wvu.edu

1 West Virginia University, Morgantown, WV, USA 
holding of King Leopold II and its subsequent transformation into the Belgian Congo, which ultimately gained autonomy in 1960 . Sociological work by both professionals and independent researchers provided much ethnographic material, and generally supported the right of the Belgian state to colonize. Poncelet, however, also notes opposed efforts, including the writings of Mark Twain attacking Leopold and the participation of sociologist Robert Park in the Congo Reform Association. The historical materials provide an inconclusive picture regarding the extent to which sociological research in the Congo served as a basis for its administration. It might have generally remained in the genre of "professional," rather than "policy," if we apply Michael Burawoy's typology.

Pieter Vanden Broeck and Eric Mangez focus on the concept of "social transaction," which originated in Belgian sociology, and its international relevance and spread. The concept is highly nuanced and thus perhaps accords with Herbert Blumer's well-known discussion of "sensitizing," rather than definitive ideas. Vanden Broeck and Mangez emphasize the ambiguities that arise from the "give and take" between notions of production and reproduction, exchange and negotiation. The very opacity of social transaction, they conclude, is perhaps the greatest strength of the concept, for the simple reason that human social life and interaction are nowhere perfectly transparent. In American sociological literature, Robert Merton's writings on ambivalence-which involve a mostly unrecognized dialectic - are arguably related. Many everyday transactions should perhaps not be seen so much as "either-or" as "both-and." Perhaps Georg Simmel deserves to be mentioned here as well.

Andrew Abbott provides a reflective and thought-provoking "afterword" to this set of papers. I will not attempt to summarize here his insightful remarks on the individual articles. But below I will add a few comments to Abbott's observations on the problems of sociology in the United States that perhaps result from the virtual pillarization of universities into such self-contained worlds as medical centers, professional schools and colleges of arts and sciences. In true "Chicago sociology" style, he suggests that sociology's location in a declining pillar, namely undergraduate colleges, might work against its flourishing.

There has long been a recognition of different schools of thought in the field, all the way back to the early split between Comtean and other "positivist" approaches and Marxist-style critiques. In 1928, Pitirim Sorokin's Contemporary Sociological Theories, though highly critical of many analyses, concluded with a vision of diverse flowers blooming in a sociological garden - a view that he would later call "Integralism." In 1970, Alvin Gouldner presented a contrasting, conflict-oriented assessment in The Coming Crisis of Western Sociology, where he condemned some approaches as detached from empirical reality. In 1974, Jeff and Carolyn Mullins's analysis of Theories and Theory Groups in Sociology pointed toward increasing separation among parallel networks of professionals. Don Levine, two decades later, recognized diversity but called for collegial dialogue in Visions of the Sociological Tradition. More recently, Jonathan Turner published an article in this journal on "differentiation without integration" in sociology, which he considers a danger to the field's long-term viability. Sarah Cawley likewise warned in a 2019 article in this journal of "encampment" and non-communication between sociologists with opposed perspectives. 
It has become clear that one can make a career in sociology within a selected subworld, a "pillar" as it were with its own membership, resource base, professional associations, conferences, publication outlets and system of rewards. During the past century, symbolic interactionists, quantitative researchers, ethnomethodologists, qualitative analysts, Marxists, feminists and others have created separate realms of sociological work and practice. To a certain extent this can be considered natural, normal and healthy, an instance of growth leading to increased complexity. However, Talcott Parsons (following Spencer) was, I believe, correct in pointing out that a system's endurance requires an integration of specialized parts - implying of course that as more and more specialized parts emerge there need to be greater and greater efforts at integration, if unity is to be preserved.

Perhaps sociology should not be regarded as a system in what Abbott has called the "system of professions," and perhaps a sense of solidarity or at least mutual respect can be maintained on some other basis. But what seems particularly regrettable is the development of increasing suspicion, distrust and animosity among colleagues in the various sub-worlds of the field, including an attitude that I have described as "an enemies mentality." Is this the future of "sociological pillars"? Are we now experiencing what Sorokin called "polarization in periods of crisis," a parting of the ways, perhaps rooted especially in competing commitments to an ethos of science and an ethos of politics? Should sociology, like Belgium, be partitioned, at least informally, as a means of accommodation and conflict reduction?

Complementing the papers on Belgium are three other excellent articles. Joseph Hermanowicz and Kristen Clayton address the issue of the relationship between race, ethnicity and publication patterns in peer-reviewed journals and in books. The authors examine data for four groups-Asians, African Americans, Latinos/Latinas and Whites - with attention also to differences between age-based cohorts. They conclude that methodological preference, especially quantitative versus qualitative, is a key factor influencing the amount of publications in top-tier generalist journals. Other differences in the quantity of journal articles among the four groups are attributable in part to the relative rates of sole authorship and co-authorship. Interestingly, there are fewer differences across racial and ethnic groups in the production of academic books.

Jerry Jacobs and Nissim Mizrachi look at the issue of diversity from another angle, namely, that of international representation in the two leading generalist journals in the U.S., comparing these with prominent journals in several other social-science disciplines. They find that journals outside sociology, such as The American Economic Review and The American Political Science Review, have a higher proportion of both international topics and of international authors. This leads the Jacobs and Mizrachi to express concern that a disproportionate focus on the United States in both The American Sociological Review and The American Journal of Sociology may be restricting the sociological imagination needed to comprehend a fast-changing global social order.

This issue concludes with an insightful and provocative article by Richard Swedberg on the uses of metaphors in sociological thought. Drawing on an interdisciplinary literature and especially the work of I. A. Richards, the author emphasizes the practical dimension of working with metaphors. This includes an examination of how to construct new metaphors, how to add to existing ones, and what happens when metaphors lead sociological analysis astray. Such issues are perennial, since 
understanding new phenomena always begins by reference to phenomena already understood to some degree. To comprehend one thing in terms of another is, of course, the basis of all metaphor. In earlier times, sociologists compared societies to organisms, ecological plant communities or cybernetic systems, while more recently, as "liberation sociology" has become hegemonic, they have portrayed societies as conquests and prison camps. Such framings, especially when they become dogmatic, make it difficult to imagine social phenomena in other ways. Considered as structures, metaphors both enable and confine.

Metaphors also point to the issue of sociological vocabulary. In earlier periods, efforts to emulate the natural sciences resulted in a vocabulary that was largely mechanistic and organic, with "equilibrium" and "solidarity" and "social forces." Somehow, in that sociocultural context, such words "sounded scientific," whereas "friendship" or "affection" did not. To use William James's types, science was "tough-minded," not "tender-minded" or, we might add, tender-hearted. Despite Comte's writings on altruism, and later efforts by Sorokin, this term has not spread widely, and a search of the indexes of introductory sociological textbooks and theory readers would locate few, if any, instances of the word "love" or related ideas such as hope and happiness. What searchers might notice is an ever-expanding vocabulary of pathology and conflict, deeply rooted in anger and animosity. So, what language will sociologists speak in times to come? In addition to the dialects of detached analysis and outraged critique, can there also be a language of celebration as suggested by Lissa Yogan in her 2014 North Central Sociological Association presidential address on "positively teaching positive sociology?"

Publisher's Note Springer Nature remains neutral with regard to jurisdictional claims in published maps and institutional affiliations. 